\title{
Recent Developments in the Study of Arid Lands
}

\section{by Owen K. Davis}

Arid lands provide data of immense value in unravelling paleoclimatic history, in assessing the effects of human activities on climate, and in predicting future regional and global changes. Ancient playa deposits in the hyper-arid core of the Sahel, loess and fossil soils, cave deposits, and desert varnish are all proving to be sources of new useful data in establishing paleoclimatic sequences. (Ed.)

\section{Why Deserts are Important for Paleoclimatology}

The deserts of the world, by virtue of their extreme aridity, are among the global ecosystems most sensitive to climatic change. In the past few years, paleoclimatic study of arid regions has witnessed a dramatic growth, fueled by interest from several areas. First, the atmospheric concentration of $\mathrm{CO}_{2}$ will double in the next century, increasing global temperatures and potentially expanding some deserts. The extent of deserts during the Holocene, when $\mathrm{CO}_{2}$ concentrations were greater, can serve as a predictor for the effects of greenhouse warming. Second, historic desertification in some arid regions represents an intensification of climatic trends that began in the late Holocene (e.g. Petit-Maire, 1986 -Ed.). Paleoclimatic studies of arid lands provide a baseline for evaluating the effects of anthropogenic disturbance.

A third factor is the recent increase of lake levels in the arid western U.S.A., which has had severe economic consequences. Study of the relationship between prehistoric lake levels and climate may help to predict future lake levels. Fourth, climatic histories of arid regions effected by monsoonal precipitation have been successfully modelled by General Circulation Models (GCM's). These computer models indieate a strong influence of insolation (incoming solar radiation) on the history of monsoonal precipitation (Sellers, 1984; Kutzbach and Guetter, 1986; Fairbridge, 1986 -Ed.), but further research is needed to check the predictions of timing and extent of monsoonal precipitation.

\section{Playas, Lakes and Paleosols}

The dramatic increase in paleoecological studies of arid regions has resulted both from intensive study of traditional deposits and from the development of new techniques. Throughout most of the world, a primary source of paleoclimatic information is aquatic sediments: bogs, marshes, and lakes. Such deposits are rare in arid regions, but new kinds of playa deposits have been discovered in the hyperarid core of the Sahara (Ritchie et al., 1985), and the analysis of modern pollen dispersal and sedimentation processes in the salt lakes of Australia greatly enhances the interpretation of pollen in their ancient sediments. Among the most sensitive indicators of changes in precipitation are lake levels, intensive study of which in western North A merica has produced a revision of earlier chronologies.

The study of fossil soils has provided paleoenvironmental data in many arid regions where no other source of information is available (Gile and Grossman, 1979). The analysis of carbon isotope ratios in snail shells preserved in the loess deposits of the Negev Desert has confirmed paleoclimatic reconstructions based on other types of indicators. From about 10,000 to 8,000 years ago the vegetation of the Negev grew under conditions more mesic (moderately humid) than today, and the $300 \mathrm{~mm}$ isohyet for precipitation extended farther to the south. Subsequently, the climate of the region became progressively more dry, gradually approaching modern values (G.A. Goodfriend, personal communication).

\section{Caves and Rock Shelters}

Environments of deposition comparable to the lake basins of mesic regions are provided by caves and rock shelters (Fig. 1). Caves are common in many arid regions, and their stratified deposits frequently contain excellently preserved plant and animal remains. They have long been recognized as important sources of vertebrate fossils in Europe, but preservation of pollen in the caves of these mesic regions is often poor (Dimbleby, 1985). In contrast, the lack of moisture retards biological oxidation in arid caves, and long sequences of well-preserved pollen have been recovered.

The processes of dispersal and deposition of pollen in eaves has not been as extensively studied as for lakes (e.g., Davis, 1968), but airborne deposition in caves has been studied with glycerin-coated slides by Dimbleby (1985) and in a network of surface samples by O'Rourke (personal communication). Water transport of pollen and fossils is important in some caves (Davis et al., 1986), particularly far from the entrances of long caverns. Animals are an important source of vertebrate remains in caves, and packrats (Neotoma spp.), bats, and other cave-dwelling animals transport plant remains, including pollen, to their nesting sites.

A'rchaeological studies are another important area of cave study, and investigations of caves and rock shelters frequently include analyses of plant and animal remains (e.g., Aikens, 1970; Bedwell, 1973; Jennings, 1980). Extensive

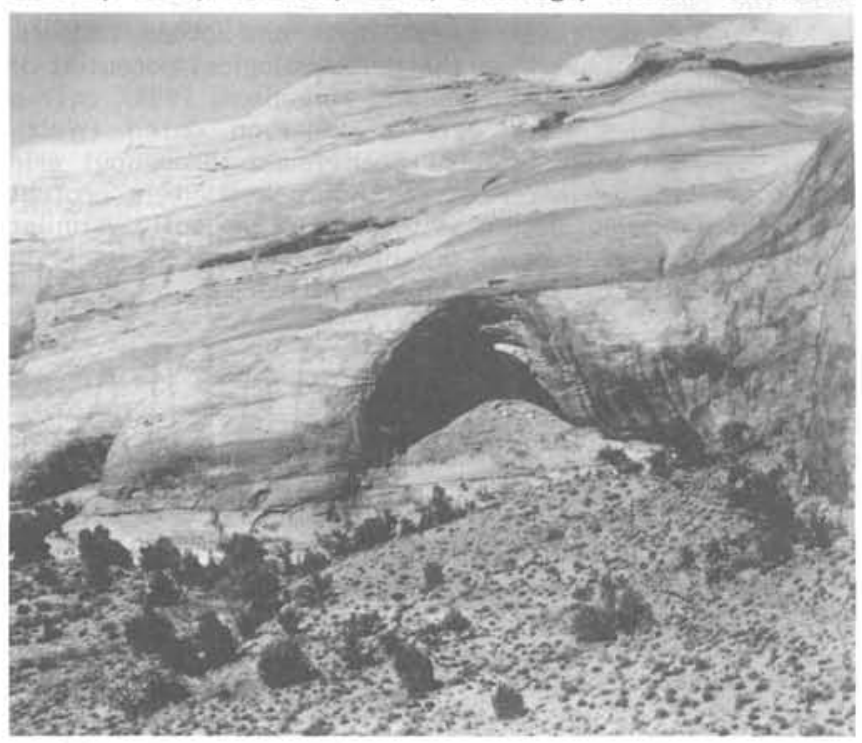

Figure 1: Bechan Cave, Utah, which contains an extensive deposit of the dung of mammoths (Fig. 2) and other extinct animals. Blue spruce, birch, sagebrush, and shadscale were prominent during the late glacial. From Davis et al. (1984) 


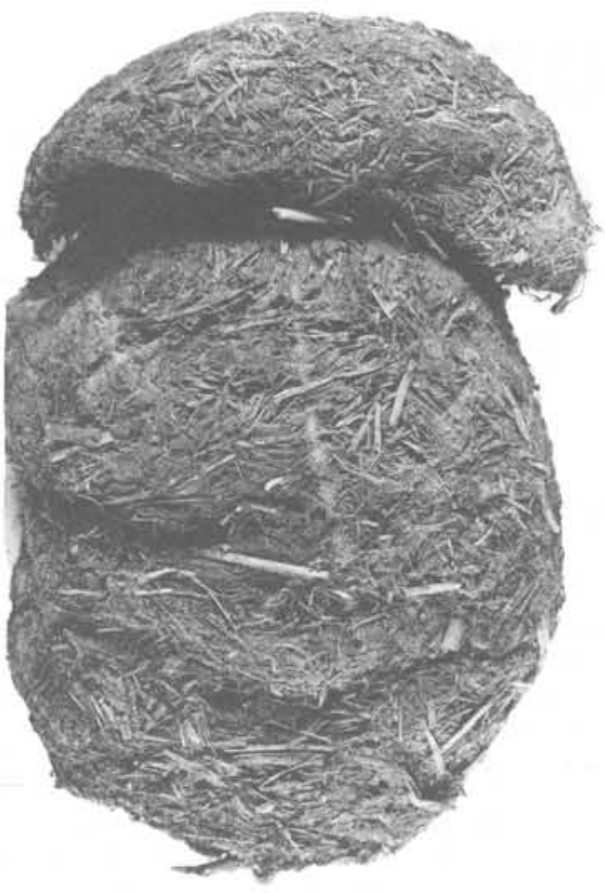

Figure 2: An 11,670 year-o1d bolus (M-1) from Bechan Cave, comprised of $98 \%$ grass and $2 \%$ shadscale. From Davis et al. (1984)

radiocarbon analysis typical of archaeological exeavations provides a firm chronology for paleoenvironmental investigations. Yet another type of cave study involves extinct animals. Dry caves in the southwestern United States (e.g., Martin et al., 1961; Davis et al., 1984) have produced such perishable remains as soft tissues and dung (see Fig. 2) of extinct Rancholabrean megafauna comparable in auality with those preserved in permafrost. Analysis of these deposits has been used to indicate the diet of these extinct organisms and to date their demise.

Perhaps the kind of cave deposit most intensively studied over the past few years has been the remains of nests (middens) left in caves by packrats and other rodents. Following the discovery of the paleoecological potential of these deposits by Wells (Wells and Jorgensen, 1964), over a thousand samples have been radiocarbon dated (Webb, 1986). Ancient middens have been found throughout arid North America wherever eaves and rock shelters protect them from dissolution by water. More recently, similar deposits, left by different organisms, have been found in South America, Australia, and South Africa.

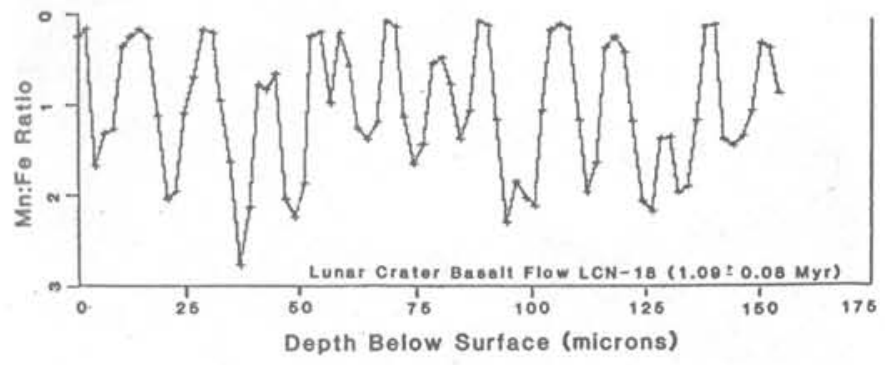

Figure 3: $\mathrm{Mn} / \mathrm{Fe}$ ratio in a layer of rock varnish from the Lunar Crater area of southern California. Lower ratios indicate more alkaline (arid) environments, whereas higher ratios reflect less alkaline (semiarid) environments. Diagram by R.I. Dorn.
Desert Varnish

Perhaps the most innovative approach to the study of desert paleoecology has been the analysis of desert varnish. This ubiauitous coating of rocks in arid regions is now thought to be of biogenic origin, laid down by mixotrophic bacteria. The analysis of the organic fraction of the varnish has, through Tandem Linear Accelerator and Mass Spectrometer technology permitted the dating of deposits whose age could be estimated by no other means (Dorn et al., 1986). The measurement of carbon isotope ratios in the varnish has permitted the evaluation of past climatic change, again in situations where no other technique is available. Since growth of desert varnish is episodic, painstaking analysis of the deposits ean produce individual layers deposited during different climatic intervals. Desert varnish with as many as 12 events deposited over the last one million years has also been found (Fig. 3).

These techniques have produced paleoclimatic sequences for arid regions where none were previously available. Climatic sequences developed in mesic areas have been shown not to apply in many arid regions. The contrast is an important contribution to Quaternary study.

INQUA '87. Special Session 32: Paleoenvironmental Reconstructions from Arid Lands. Organizers: O.K. Davis (U.S.A.) and L. Scott (South Africa).

Dr. O.K. Davis teaches at the Department of Geosciences at the University of Arizona (Tueson, Arizona 85721, U.S.A.). A member of the INQUA Subcommission on the Holocene, he works on the analysis of pollen and plant macrofossils from sites in Idaho, Utah, California, and Arizona, the effects of the astronomical theory of elimatic change on seasonal climate, and the diet of extinct megafauna.

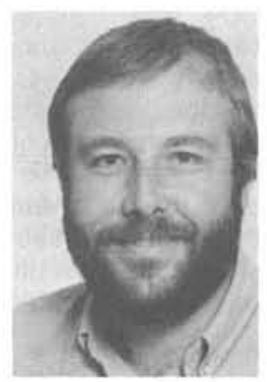

\section{References}

Aikens, C.M. 1970. Hogup Cave. University of Utah, Anthropological Papers 93. Bedwell, S.F. and Ray, V.F., 1973. Fort Roek Basin: prehistory and environment. University of Oregon, Eugene, Oregon, 189p.

Davis, M., 1968. Pollen grains in lake sediments: redeposition caused by seasonal water cireulation. Science, v. 162, no. 3855, p. 796-798.

Davis, O.K., Agenbraod, L.D., Martin, P.S, and Mead, J.I., 1984. The Pleistocene dung blanket of Bechan Cave, Utah. Carnegie Museum Natural History Special Publication v. 8 , p. $267-282$.

Davis, O.K., Sheppard, J.C. and Robertson, S., 1986. Contrasting climatic histories for the Snake River Plain, Idaho, resulting from multiple thermal maxima. Quaternary Research, v. 26 , no. 3, p. $321-339$.

Dorn, K.I. et al., 1986. Cation-ratio and accelerator radiocarbon dating of rock varnish on Mojave artifacts and landforms. Seience, v. 231 , p. 830-833.

Dimbleby, G.W., 1985. The Palynology of Archaeological Sites. Academic Press, London, $176 \mathrm{p}$.

Fairbridge, R.W., 1986. Monsoons and paleomonsoons. Episodes, v. 9, no. 3, p. 143-149.

Gite, L.H. and Grossman, R.B., 1979. The desert soil project monograph. Soil Conservation Service, U.S. Department of Agriculture, 984p.

Jennings, J.D., 1980. Cowboy Cave. University of Utah Anthropology Papers 104.

Kutzbach, J.E. and Guetter, P.J., 1986. The influence of changing orbital parameters and surface boundary eonditions on elimatic simulations for the past 18,000 years. Journal of the Atmospheric Seiences, v. 43, p. 1726-1759.

Martin, P.S., Sabels, B.E. and Shutler, D., Jr., 1961. Rampart Cave coprolite and ecology of the Shasta ground sloth. American Journal of Seience, v. 259,no. 2, p. 102-127. Petit-Maire, N., 1986. Palaeoelimates in the Sahara of Mali. Episodes, v. 9, no. 1, p. 7-16.

Ritehie, J.C., Eyles, C.H. and Haynes, C.V., 1985. Sediment and pollen evidence for an early to mid-Holocene humid period in the eastern Sahara. Nature, v. 314, p. 325-355.

Sellers, W.D., 1984. The response of a climate model to orbital variations. In: Berger, A, et al., (eds.) Milankovitch and Climate. D. Reidel, Dordreet, p. 765-788.

Webb, K.H., 1986. Spatial and temporal distribution of radioearbon ages on rodent middens from the southwestern United States. Radiocarbon, v. 28, no. 1, p. 1-8.

Wells, P.V. and C.D. Jorgensen., 1964. Pleistocene wood rat middens and elimatic change in the Mojave Desert: A record of juniper woodlands. Science, v. 143, no. 3611, p. 11711174. 